This is the accepted version of the article published by Wiley: Maestripieri, L., and Cucca, R., Small is beautiful? Emerging organizational strategies among Italian professionals, Canadian Review of Sociology, Vol. 55, Iss. 3, 2018. The final version is available at: https://onlinelibrary.wiley.com/doi/abs/10.1111/cars.12208

\title{
Small is beautiful? Emerging organizational strategies among Italian professionals ${ }^{1}$
}

Lara Maestripieri (Universitat Autònoma Barcelona) and Roberta Cucca (Norwegian University of Life Sciences)

\section{$\underline{\text { Abstract }}$}

The traditional debate about professional groups has mainly focused on conflicts between professions and organizations, reinforcing dualisms and dichotomies. Few scholars have investigated the extent to which professionalism and organizations are intertwined, while focusing on the case of professionals integrated into large organizations, and even less attention has been paid to emerging forms of organization among self-employed professionals.

Taking as an example organizational trends among architects (liberal professionals) and management consultants (emerging professionals) in Italy, this article investigates how small, flexible, (often) inter-professional organizations promoted by self-employed professionals are increasingly instrumental in overcoming market pressures and responding to emerging social needs in times of crisis and austerity.

\footnotetext{
${ }^{1}$ Although the article is the result of a collective work, it is possible to assign authorship of section 2 and 3 to Lara Maestripieri, section 4 and 5 to Roberta Cucca. Introduction and conclusions are authored collectively by all authors.
} 
Résumé

Le débat traditionnel à propos des groupes professionnels a principalement concerné les conflits entre professions et organisations, renforçant ainsi les dualisations et dichotomies entre ces deux groupes. Peu entre les chercheurs ont investigué à quel point professionnalisme et organisations se retrouvent de plus en plus souvent, se concentrant particulièrement sur le cas des professionnels appartenant à de grandes organisations. Cependant, moins d'attention a été prêtée aux formes organisationnelles émergentes entre les professionnels indépendants.

En prenant comme exemple les architectes (professionnels libéraux) et les professionnels dans le conseil en management (professionnels émergents) qui travaillent en Italie, cet article analyse comment les organisations des professionnels indépendants, qui son petits, flexibles, (souvent) interprofessionnelles, se transforment en outil pour faire face à la pression du marché et pour répondre aux besoins émergents en temps de crises et austérité.

Keywords: professionalism, organization, public regulation, liberal professions, emerging professions. 


\section{Introduction}

Sociological debate on professions has traditionally viewed professionalism as an occupational strategy: unlike other occupations, professions constitute a differentiated means of organizing work and controlling workers based on peer control (Freidson 2001; Evetts 2011a). Defined as such, professionalism is inherently contradicted by the market and bureaucracy, which can be considered organizing logics that rely respectively on hierarchy and on consumer choice to exercise control (Freidson 2001; Evetts 2013). Consequently, the traditional debate on professional groups has more frequently focused on conflicts and trade-offs emerging within professional organizations, defined as bureaucratic forms organizing the work of professionals (Malhotra and Morris 2009; Noordegraaf 2011; 2016). These studies have primarily focused on professionals integrated into large firms or institutions (Faulconbridge and Muzio 2007; Malhotra and Morris 2009; Muzio et al. 2011; Schott et al. 2016), while relatively lesser attention has been paid to analysing other forms of professional organizations (Cooper et al. 1996; Leicht and Fennel 1997; Evetts 2011b; Noordegraaf 2011).

This article will focus on an under-investigated but emerging phenomenon, namely organizational trends based on solidarity mechanisms and intra- and inter-professionals networking among selfemployed professionals. Specifically, it will consider the condition of architects and management consultants in Italy, where historically self-employed professionals have extensively promoted professional partnerships between colleagues (in the form of associated firms), but new organizational trends are emerging today in order to overcome challenges originated by market crisis and welfare austerity. Architects and consultants in Italy, although starting from a different regulatory condition and different market situations, are increasingly interested in organizational forms that go beyond the traditional model of professional partnerships. Flexible organizational structures seem to respond better to their needs in terms of social protection, both in terms of vulnerability associated with lifecycle events (maternity leave, care leave, illness, and pensions, 
etc.) but also in terms of providing protection against loss of wages as a result of market crisis (Cucca and Maestripieri 2014). These organizations also constitute a way to signal professionalism in the market (Evetts 2011a), considering the reduced role of professional associations. These trends are particularly important, as they have been executed bottom-up by professionals, as the institutional crisis of the Italian system of professions has become more and more evident. On the one side, liberal professionals, such as architects, are increasingly exposed to market pressure as the traditional mechanisms of social closure begin to crumble. On the other side, management consultants undertake their professional activities in the absence of any clear regulation of the market (Cucca and Maestripieri 2014).

The scope of the article includes an investigation of how small, loosely formed, organizations are becoming tools for overcoming market pressures in the case of self-employed professionals. The originality of the investigation lies in the research design, which consists of a comparison between a liberal profession (architecture) and an emerging profession (management consultancy). It is distinctive as it involves an inter-comparison analysis of organizational practices (Malhotra and Morris 2009), and studies of professional groups in the domain of sociology have typically relied upon single-sector investigations. By contrast, this inter-professional comparison stresses the differences between professionals beyond their initial diversity in terms of institutionalization. Indeed, the results of the investigation show that tendencies in organizing professionalism are transversal trends that equate architects and consultants. These trends are related to the increasing vulnerability of freelance professionals (Leicht 2017), while the content and the regulation of professional activity appears to play a more marginal role in defining professionalism.

The article will be structured as follows. First, a literature review will be conducted discussing the complex relations between organizations and professionalism. Second, the aims and structure of the empirical investigation will be briefly presented. Third, the conditions of architects and consultants will be compared by describing the differences in public regulations affecting the two groups and 
by focusing on two specific cases that represent emblematic examples of using organization as a survival strategy in the labour market. Finally, the paper will present evidence of two ideal types of organization occurring among self-employed professionals in Italy: the mutual association, and the shamrock organization (van den Born and van Witteloostuijn 2013).

\section{Professions and organization in recent sociological debate}

According to the neo-Weberian perspective, professionalism can be defined as a system of control of an occupation, which is enacted by peers in relation to a jurisdiction over a certain knowledge base (Saffatti Larson 1977; Abbots 1988; Evetts 2003). Following this approach, professions can be distinguished on the basis of their occupational strategies (Fincham 2006), excluding as professionals all those who have not followed the 'ideal' professionalization course identified by Wilensky (1964). This assumption carries two important theoretical consequences. First, all those occupations that lack any institutionalized control of access cannot be defined as professions, as, for example, is the case of emerging professions. Emerging professions are defined as those professional activities that are in the process of professionalization but are yet to be recognized as professional by public regulation, although their practitioners lay claim to professionalism. Second, professionalism is mainly in contrast with other forms of work regulation, such as the market or bureaucracy (Freidson 2001, Muzio et al. 2013; Noordegraaf 2011).

There has thus been vigorous debate regarding the extent to which organizations might undermine power, autonomy, and the privileged status enjoyed by professionals (Noordegraf et al. 2014; Waring 2014). Brock (2006) argued that professionals are subjected to heteronomous control when working within bureaucracies. Later, Marie Haug $(1973 ; 1975)$ proposed the idea of deprofessionalization, as a consequence of loss of autonomy in working performance and routinization of professional tasks, with more and more professionals becoming involved in large 
companies. According to the proletarization hypothesis (McKinlay and Stoeckle1988), the upsurge in large institutions implies that professional services, instead of consisting of a relation between a client and a competent expert, become commodities sold on the market in exchange for a salary. (Waring 2014). Finally, Freidson (2001) argued for the incompatibility between professionalism and the competing and mutually exclusive logics of organizations and bureaucracy.

Various evidence is put forth in the literature to support the argument that organizations are placing limits on traditional professional work (Leicht and Fennel 1997). Firstly, standards of quality and efficiency, which require organizing practices, routines, and criteria may hinder the autonomy of professionals in organizations (Devine et al. 2000; Noordegraaf, 2011; Currie et al. 2016). Secondly, the control exercised by managers in organizations could conflict with the control exercised by peers, thus hindering the professional 'dominance' (Leicht and Fennel 1997; Freidson 2001; Faucoulnbridge and Muzio 2007; Evetts 2013).

However, such debate neglects the reality of the contemporary situation. An institutional context opposed to monopolistic closures (Noordegraaf 2007; Noordegraaf and Schinkel 2011; Butler et al. 2012; Hodgson et al. 2015) implies a process of deregulation, causing new vulnerabilities and insecurities among professionals (Cucca and Maestripieri 2014), and questioning the legitimacy of their privileged status (Cohen et al. 2005). In addition, these scholars also overestimate the effect of organizations on professionalism, while underestimating the opposing influences, with professionalism revising the way in which organizations operate (Malhotra and Morris 2009; von Nordenflyck 2010). Moreover, many scholars have ignored the role played by the context in which work is performed when examining the relationship between professionalism and organizations (Leicht and Fennel 1997; Schott et al. 2016). Furthermore, post-industrial societies have redefined occupational distribution, with a growing number of expert occupations (Hanlon 1996; Muzio et al. 2008; Fincham 2012) favouring new processes of professionalization. Professionalization in emerging professions is characterized by intrinsic organizational needs, calling into question the 
universality of the path followed by liberal professionals (Kipping et al. 2006; Muzio et al. 2008; Hodgson et al. 2015).

From the above starting points, a more critical perspective has been put forth by various scholars. Bucher and Stelling (1969), in a paper based on a series of studies in different professional organizations, argued that bureaucratic theory is of limited value in understanding professional organization, since professionals create their own distinctive social organizations within larger ones. Mintzberg (1979; 1983) directly questioned the de-professionalization hypothesis, and theorized the concept of professional bureaucracy to describe professionals working as managerial staff in bureaucratic structures (Brock 2006; Malhotra and Morris 2009). Hanlon (1996; 1998) introduced the category of commercialized professionalism, emphasizing privileged relations within markets in which certain activities take place (Fincham 2012). This implies that the idea of undertaking a role or task expertly (Hanlon 1996) is a client-driven definitional criterion for professionalism that relies on making the buyer content.

Going further, Noordegraaf $(2007 ; 2011 ; 2015 ; 2016)$ questioned the loss of professional autonomy that should supposedly result from liberal professionals' embeddedness in organizations. First, the organization of tasks is not necessarily at odds with being a professional (Evetts 2011a; 2011b); it is part of the role of senior professionals (Waring 2014) and freelance practitioners (Cucca and Maestripieri 2014). Second, organizational forms are needed to render professional services (Noordegraaf 2011). New ways of organizing professionalism (Noordegraaf 2011; 2015; 2016) base their heuristic power on interweaving between professionalism and organizations, which is necessary to react effectively to a changed contextual environment (Schott et al. 2016).

To a large extent, however, the current debate on professionalism and organization still suffers from a limitation in that it is a legacy of the typical productive structure that characterizes Anglo-Saxon countries, where the majority of these studies have been conducted. When discussing organization 
and its interactions with professionalism, scholars typically envisage large corporations and complex hierarchical structures, identified within the literature via different labels, including managed professional businesses, reconstructed professional firms, and professional firms (Alvesson 2001; Greenwood et al. 2005; 2006; von Nordenflick 2010). Still, the organizational context in which professional services are rendered might be very different from this model, especially in a context such as Italy where the productive system is mostly composed of small and medium enterprises (SMEs) (Colli 2010). In particular, what is often forgotten is the role played by self-employment in defining professionalism, which is also extremely diverse within itself (Cucca and Maestripieri 2014), ranging from freelance individuals to entrepreneurs running small companies organized into professional partnerships. In the case of solo practitioners, organizational control and limitations are absent, while relations with a community of peers is not mediated by any organization, but instead via the personal network of each professional (Suddaby et al. 2009). In the case of SMEs, professional partnership still represents the main form by which independent professional services are rendered in the Italian context (Ranci 2012). The model theorized by Greenwood, and subsequently refined by Brock (2006), stresses internal democracy, professional involvement in management, and control characterized by informality and collegiality (Greenwood and Empson 2003; Faulconbridge and Muzio 2007; Malhotra and Morris 2009), and in the Italian case specifically is characterized by the reduced dimensions of partnerships (1-2 practitioners) (Ranci 2012).

This study will show that even in self-employment micro-contexts, organizational practices are increasingly taking place amongst independent professionals too, in unexpected ways that theorists of the de-professionalization hypothesis could not have foreseen when considering only organizations of larger dimensions. 


\section{Methodology}

The data presented in this article were collected over the course of a two-year research project on the political economy of middle class independent workers in Italy, of which professionals were just one branch. In this project (2008-2012), professionals were compared to shopkeepers and entrepreneurs with small enterprises. Its main goal was to study the transformation of selfemployment in Italy over the previous decade, taking into account traditional territorial differences in Italy that give rise to different degrees of economic vulnerability in the local productive structure. The article presents the empirical results of 44 semi-structured interviews: 23 with self-employed management consultants, and 21 with architects. These individuals were based in three different areas of Italy - 20 in Milano and Lombardy in the north; 13 in Marche and Ancona in the central region; and 12 in Campania and Naples in the south - and represented different types of local Italian productive systems (Bagnasco 1977). Consultants had an average age of 51 years, and six were women. Architects had an average age of 43, and 10 were women. Interviewees were all selfemployed, with 18 of the 21 architects being solo freelance professionals. In the case of consultants, there was a more varied occupational profile, as many were owners of small businesses with one to three dependent workers ( 9 out of 23 were owners and/or business partners of an SME).

The interviewees were sourced through personal contacts and professional associations, supplemented by snowball sampling techniques. The different regulative practices between consultants and architects also had an impact on sampling. In the case of the architects, the population of practising professionals is publicly known, as they have an obligation to subscribe to local bars to provide professional services. This list made the process of identifying interviewees easier, as the names of potential candidates were made available through the Architects' Order. In the case of consultants, there is no established bar, and no professional associations able to represent the various actors in the sector (Maestripieri 2016). The lack of representation is even greater for freelancers and small businesses, as the main association of consultancy firms 
(Assoconsult) includes among its 400 members all the biggest players in the market (Assoconsult 2015), while the association for self-employed consultants (APCO) has approximately 1,500 members, which represents only a minority of the potential population (previously estimated at 45,000 practitioners) (Maestripieri 2013). In the case of management consultants, interviewees were mostly sourced via initial contact with members of the APCO, followed by snowball sampling.

Three dimensions were investigated using a content-analysis approach: each interviewee's ideas about professionalism; their efforts to become autonomous; and their entrepreneurship style. One section investigated the impact of social protection and professional acknowledgement on general work satisfaction.

This article focuses on two emblematic cases in order to illustrate how professionals in Italy are returning to networks and organizations. Drawing on a more generalized analysis of the organizational strategies of professionals conducted by Cucca and Maestripieri (2014), the two cases are important to stress convergent strategies in the hybridization between professionalism and organization (Noordegraaf 2011). However, it is important to emphasize that the proposed cases highlight an emerging trend among Italian professionals. While the results are not intended to be generalized, the analysis allows the reader to obtain insight into the changing relationships between professionals and organizations, which opens up new directions for the analysis of this interplay, and which constitutes one of the main debates in current research on professions.

\section{The system of professions in Italy: regulative cleavages}

The system of professions in Italy represents a peculiar case that is useful to emphasize the recent transformation of the professional market, which affects relationships between professionalism and organizations. Professions are regulated in Italy via a system of orders and registers for liberal 
professions; these were defined in the $19^{\text {th }}$ century (Malatesta 2006; Micelotta and Washington 2013). These 'protected' professions are accessible only by acquiring formal credentials, which consists in obtaining a specific university degree for each profession, passing a state exam to certify their competencies, and being included in a register of professionals (Malatesta 2006). Belonging to an order also means having access to a series of rights, including special criteria for social protection, a privileged regime for the payment of taxes, and protective regulation. Until the Bersani law (L. no. 248/2006) was passed, regulation of liberal professions prohibited advertising and multidisciplinary practices, also fixing minimum and maximum fees (Micelotta and Washington 2013). This lengthy procedure, which in the past was a mechanism of social protection for the professional group, at least in terms of controlling numbers of new entrants, has not been able to control the architectural market in the past 10 years (Cucca and Maestripieri 2014). Meanwhile, the success of neoliberal policies in western economies has promoted strong opposition to labour market regulation, calling into question the privileged position of those working in roles in which they are recognized as professionals (Neal and Morgan 2000). Being strongly corporatist-orientated, the Italian system of professions has not been able to govern the shift towards the post-industrial economy, as the institutional setting has been recently updated, and with extreme difficulty in the context of extreme conservatism (Micelotta and Washington 2013).

Transformation of the system of professions in Italy has also implied uncontrolled growth in the number of professionals offering services outside of the system of orders, in connection with the increasing importance of activities framed within the knowledge economy (Brint 2001). Emerging professions as such are characterized by a residual juridical institution, in which there is no regulation by public institutions, and no control regarding access to the market or standards of provision of professional services (Cassese 1999). Conversely, these professionals are entirely free to provide their services in the preferred organizational form without the limitations imposed by enforced membership of any order. Their members are free to join professional associations, but 
associations are not recognized by the state and they are not state-sanctioned as orders (Micelotta and Washington 2013, Maestripieri 2016). While the Italian government has not provided individuals in emerging professions with traditional integration through orders and bars, there is also no formal acknowledgement of their professionalism.

The two professions of architecture (liberal profession) and management consultancy (emerging profession) are of particular interest in this regard because of a transformation in the numbers and composition of each profession over the course of the last twenty years. In the case of architects, the number of professionals has increased at a high rate in recent years. Italy is the European country with the highest number of architects, with 2.5 architects for every 1,000 inhabitants. There are several reasons for this. First, architects have been growing in number because of the increased number of women entering the profession. Women now account for approximately $38 \%$ of architects. In addition, the significant growth of the housing market in Italy before the financial crisis, plus the traditionally strong social recognition associated with this career, have attracted many students to this profession in recent years. Even during the crisis, which strongly impacted revenues, the number of architects continued to grow. Finally, only $9 \%$ of architects receive a salary as a dependent worker (counting private and public sector employees); there is an orientation toward self-employment that is peculiar compared to the rest of Europe. This situation has destabilized the traditional form of social protection that liberal professionals previously experienced, which was based on social closure, as architectural institutions do not have enough power to impose a cap on new entrants. Further, the formal regulation currently affecting liberal professions appears to be insufficient to protect their professional activities. The resulting market pressure has generated a growing vulnerability, especially for the youngest and most fragile professionals, as solo freelancers (ACE 2014).

Management consultants, by contrast, have never based their market success on ensuring a monopoly for their activities, since consultancy is completely deregulated in Italy. Nevertheless, it 
is an economic niche that, despite the financial crisis, has maintained the same level of revenue that it had before the crisis (ASSOCONSULT 2011). However, in accordance with the traditional approach to professionalism characterizing Italy, consultants share the same predisposition toward self-employment as architects (Maestripieri 2013): approximately 85\% of management consulting firms in Italy have less than three workers (ASSOCONSULT 2015), but unlike architects there is a relevant quota of professionals (approximately 22,000 in 2015) who are employed in larger organizations (from three employees up to large corporations). The organizational context for consultants is thus more varied compared to that for architects.

The call for independency is a legacy of the Italian context, as professionalism in Italy has always been peculiar in this sense, compared to continental and Anglo-Saxon countries. In Italy, the occupational model for professionals is self-employment, whereby a freelance professional works alone in the market, or in association with 2-3 peers forming a small professional partnership. Professionals represent the largest proportion of the total self-employed workforce in Italy (Ranci 2012): in 2016, approximately 1,300 workers in Italy were self-employed professionals, $83 \%$ of who were freelance without dependent workers (Maestripieri 2013). In the last 12 years, the proportion of professionals in total self-employment has increased, showing a substantive growth rate both for those who have dependent workers $(+11.7 \%)$ and those who are freelance $(+24.3 \%)$ (Reyneri 2017).

Being self-employed has a relevant impact on the way in which professionalism is perceived amongst practitioners. Self-employed professionals make up the majority of professionals in consulting and architecture (Maestripieri 2013; Cucca and Maestripieri 2014; ACE 2014), but the accounts of the two groups reveal different perspectives on self-employment. For architects, being freelance is a TINA: 'there is no alternative' for young practitioners, as all those who want to become architects prior to the state exam must complete an internship under an acknowledged architect before becoming freelance and collaborating in the same bureau. Passing the exam also 
means that the individual can author their own project: as this is necessary to further their careers, young entrants are usually underpaid whilst completing their internship and even after they have achieved their state recognition. Bureaus usually ask them to obtain a VAT registration number, formally becoming independent but de facto working as a dependent worker, since the organization decides on their work schedule and the work they undertake. Although the risk of proletarization is clear in this process (McKinlay and Stoeckle 1988), the agency of professionals lies in the possibility offered by 'the signature': as they can sign their own projects, young practitioners can also begin to encourage their network of clients to detach from the bureaus.

"The only possibility you have [...] is to enter a bureau, but entering a bureau means doing... what they propose to you as a big courtesy, which is working for one year for free and then, if you are pretty good they do not throw you out but they offer you an expense account of $€ 300$ per month. Then, it is not that you become an associate of the bureau or something, then what it happens, even if they do not tell you at the beginning, is that if you are smart enough you go away from the studio, stealing clients from them" [Architect, M, 38].

"Then I went away, but that was not because I was not feeling well [in the architectural firm, N.d.A.], but because I wanted to walk alone, partially because I already had small assignments on my own away from the firm; partially because clients had already got to know me; and partially because my business partner and I were already working together. That is, [I went away] because I already had a pool of clients able to sustain my activity” [Architect, F, 33].

The situation is different for management consultants. They do not have the obligation of order registration and several alternatives are available to them when they complete their studies. Practitioners usually have degrees in economics and engineering, as these are more highly valued 
on the labour market, and are free to choose their own career in either 'normal' firms or consultancy corporations. Usually, younger practitioners choose self-employment because they dislike the work organization in a larger firm, but a significant number of consultants do enter self-employment later in their career because they lose their executive positions in firms when they have already 40 and 50 years old. In this last case, being independent is the preferred option over being unemployed or over-qualified.

\author{
"Being independent, being free to... accept or refuse an assignment, because \\ there are assignments that at the moment I allow myself to refuse if they are not \\ adequately paid, if I do not like them in terms of the personal and professional \\ involvement, because for me it is very important to find spaces in which I can \\ express myself"' [Consultant, M, 43].
}

Despite its popularity, while self-employment provides individuals with autonomy and potential high profits, freelance work, which is defined as self-employment without any dependent employees and without any organizational structure, also carries the risk of low income and insufficient social contributions. Especially in times of crisis, European governments' welfare provisions for self-employed workers are insufficient to ensure their wellbeing (Hipp et al., 2015). As a consequence, the real competence new practitioners must acquire is the ability to gather enough assignments to sustain themselves during the first years of their career. New entrants are quite often trapped in extremely vulnerable situations, as a result of being economically dependent on one buyer, despite being formally autonomous (Cucca and Maestripieri, 2014). Even in a later stage of their career, practitioners never escape insecurity and precariousness, whether they are architects or consultants: especially when they are working as solo freelancers, any negative life event can expose them to economic insecurity. Italian legislation considers these individuals to be entrepreneurs, and excludes them from income compensation or unemployment benefit if their turnover reduces because of market downturns (Ranci 2012). 
"Precariousness is not a phenomenon that only young workers face today, it is a phenomenon that has always existed and that I live with even now, because I do not get an income from anybody. I do not have any other employment; I do not have any support from the public beyond what I earn from my work, according to the energy that I put into this activity. Clearly this implies stress and anxiety, but also great satisfaction" [Architect, M, 46].

Nevertheless, despite the higher security that a job in a larger firm can offer, only a few of the interviewees were prepared to give up the freedom offered by self-employment. The arguments made against large firms were broadly similar across the two groups of professionals: that they oppress the creativity of professionals; they do not allow the individual to follow the entire course of a professional service or implement their own methods and techniques; and that organizations decide on the timing of activities and task distribution among professionals.

\footnotetext{
"In a spirit of freedom and independence that is typical of my character, unfortunately I am allergic to fixed schedules, I am allergic to work under rigid guidelines issued by a chief. When you work as a dependent worker for a single entity then you get tremendous advantages in terms of security and stability, but it also implies... several disadvantages in terms of freedom, and creativity; it does not allow you to express yourself" [Architect, M, 48].
}

Between the frustrations of being employed in a large organization, the experience of deprofessionalization dynamics and loss of autonomy, and the high risks of being a solo-professional in terms of labour market and welfare vulnerability, the solution identified by a growing number of professionals in Italy lies at the midway point. As will be shown in the next section, practitioners are increasingly beginning to develop networks in more institutionalized forms, utilizing small, 
flexible, inter-professional organizational forms to compensate for and cope with market pressures. In fact, the call to organize is one of the strategies developed by these professionals in order to overcome the inadequacy of the present legislation to protect them from life-course vulnerability and the extreme concurrent need to survive in the market when they are solo-professionals.

\section{Similarity in organizing}

Networks and organizations have played a substantial role in the transformation of the professional market, and they are a common trend of a post-industrial society, as has already been discussed in applicable research (Castells 1996; Boltanski and Chiapello 1999). The interviewees in the sample demonstrated significant variance in the means of organization they resorted to: from very informal networks bound together only by an intense collaboration but without any formal structure, to small organizations that use brands to signal themselves on the market. In only a few cases within the last group organizations also had a physical location, as this was considered quite risky due to the fixed costs added to self-employment.

There are several advantages that practitioners can obtain from association with their peers, typically related to commodities: grouping together allows for sharing the fixed costs of the activity (e.g. rent, secretaries, licenses), while the establishment of firms enables the financial reserves that could potentially protect personal savings in case of economic downturns. In organizations like those described in this section, partners are also self-employed professionals and receive income by invoicing their society, rather than through dividends. Therefore, the retained gains will remain within the organization and be used to pay the collaborators, and to act as a form of insurance in case of difficult periods. 
Aside from the basic economic and organizational advantages that derive from association, there are two interesting and diffuse motivations underlying the drive to exceed the model of solo practitioners, which go beyond traditional theorizations of networking.

First, organizations - even when they are extremely loose and virtual - can act as substitutes for public regulation, which is declining in its role and efficacy. If a person is temporarily unable to provide services for various reasons (maternity leave, sickness, work-family reconciliation), the organization will persist in the market thanks to the work of colleagues, allowing the individual practitioner to return to their market position without being hindered by their temporary absence. In this sense, beyond merely a space for collaboration and peer exchange, the organization becomes a strategy to cope with market pressure, defining a hybrid form of organization the main objective of which is to protect its members from the market. This form of organization is here referred to as mutual aid association.

\footnotetext{
"We as freelance professionals are a bit at risk; illness, accidents, and other such things... we immediately lose income. You can sustain lost income for a certain period, but at least the organization continues, and it should allow you the possibility of returning when you get better. Being in a group, the fact is that there is at least one other person that knows the company in which you are operating, which guarantees continuity" [Consultant, M, 54].
}

Although all professionals are exposed to market downturns, the role of organizations is particularly relevant in the case of female practitioners. For them, sustaining forced inactivity during pregnancy and reconciling work and family after the birth of their child represents further potential risks for their economic security. Being outside of the market for five to six months compromises their professional relationships: as such, freelance professionals reduce their maternity leave as much as 
possible - although it is prohibited by law - and rely on the help of their extended family, as public services do not allow for a productive reconciliation between work and family life.

"With children I always worked, up to the last moment: I have not taken a single day off! Then I started my activity again after one month. I could work at home and feed them, while being supported by my mother and my mother-in-law. I always worked because for freelance professionals there is no support: you just have to work and stop" [Architect, F, 54].

"The first difficulty I had was that my business partner, as soon as I chose to have a child, left the associated architectural firm. I alone, with a family, was not able to maintain the firm. Then I found myself facing maternity with inadequate safeguards nor services to allow me to manage an independent activity, knowing I could not leave my children to care services" [Architect, F, 40].

Second, the organizational forms can allow practitioners to divide competencies and tasks between them, which is especially important in regard to who is responsible for finding new work. Although this is part of the everyday life of self-employed professionals, the sociological debate about professionalism has overshadowed the role of commercial tasks in defining professionalism (Hanlon, 1995), even though they are essential to the survival of small firms and solo-professionals in the market. Where, in the case of a standalone professional, different roles are centralized in a single person, in the case of an association a preliminary division of task is made between members concerning who is responsible for commercial activities and who for the operational activities required for the completion of assignments. Grouping together also allows each professional to follow their own attitudes and inclinations, as organization creates a space for the division of work between partners. 
"Because if we are all together in the office or [if] we all go out of the office, we do not obtain the desired result for two reasons: if we are two, three, or four and we all stay together in the office to work on projects, there is nobody working 'on the road', and clients are found 'on the road'. If I remain in my room, when I have finished my project, how can new clients be acquired? It is impossible!" [Architect, F, 33].

"While *name* is a know-it-all and he will always want to keep learning, I, on my own, apart from the fact I do not do certain things on principle, I should also have learned many more things if I would have not had him [...] He is more entrepreneurial than me. If I could never see clients, it would be perfect for me" [Architect, F, 40].

When the association is between a man and a woman, a gendered division of roles emerges: the men are usually assigned the commercial tasks, while women are more inclined to organize the internal work amongst collaborators and the networks of sub-contractors. This segregation of roles is also influenced by a still common prejudice against women amongst clients: independent professionals usually have small enterprises or other professionals as interlocutors in their everyday working lives, persons who perceive women as less authoritative compared to men.

"We are the two owners of the studio, but my brother, who is also an architect, takes care of the administration and of the external relations, because fund raising is more effective when he manages the contacts. When we get a commission, my role is to manage it amongst my colleagues: I choose to whom a task is entrusted, and how it should be done. I also take care of operative tasks, like designing, projecting, and presenting the work" [Architect, F, 51]. 
"Consultancy is really male, that is, your boss is always a man - I have always faced this situation, eh! Oddly enough, even in large organizations that work for important manufacturing groups, the contact with the client is always managed by the male boss, you were just the infantry" [Consultant, F, 45].

An interesting deviation from this model is seen in the inter-professional association, as in the case of one of the architects interviewed for this study. The two professionals - one female architect and one male surveyor - were active in the outskirts of Naples: while she dealt with the operative development of the project, he raised new commissions and assignments. In this case, it was not only a division between commercial and operational tasks: the relative competencies of two distinct professionals supplement each other in order to offer a complete service to the individual that seeks the services of this bureau.

"That is to say, he needed my help, and I needed his, because in this specific case, his competency in terms of what he can offer the client was greatly enhanced by the fact that he could rely on the experience of an architect. For my part, I could take advantage of an established organization, and of a person with ten years' experience, so it was somewhat simple. That is to say, we found a common solution." [Architect, F, 33].

As was clearly stated during this interview, an association with other professionals helps to share investment expenses and the costs associated with the maintenance of an office. In addition, the association improves the competitiveness of the organization through the widening of the services offered as a result of the different competencies of the various partners, and through an increase in their likelihood of being successful in the market, as they assign commercial tasks to the person most effective at finding projects. Therefore, the organization becomes an instrumental tool that helps professionals to compete in the market. 
The case of consultants is particularly interesting: it builds upon the basic division of commercial versus operational tasks, but goes even further. The interviews revealed the increasing success of what has been called the 'shamrock organization' (Handy 1989 cited in: van den Born and van Witteloostuijn 2013), made up of a core of partners mostly concentrated on commercial tasks while outsourcing operational tasks to a network of freelance collaborators activated depending on projects and assignments. The advantages of this form are clear: organizations remain loose without burdening professionals with bureaucratic management, and without increasing the fixed costs of activity as dependent workers would do, while allowing practitioners to benefit from a community of experts that can be relied on and activated when needed, depending on the different assignments that they are awarded. Due to its functioning, it gives professionals the opportunity to acquire large projects owing to a wide network of specialized collaborators, but it is also flexible enough to survive when the market is weak, due to its 'scarce' structure comprised of a rented office, a secretary, and some computers.

"We have a group of professionals with whom we are able to enter into an organization and to follow it, control it, and verify it in all its aspects and in all sectors. Yes, I am involved in a network if you want to describe it with a modern term” [Consultant, M, 66].

"The structure I gave to ***, let's call it an organizational structure, is... an associated firm in which there is a founder-which is me - and associated partners. Some of them are associated to specific projects, while others are associated to almost all the projects, but we also have professionals that are summoned episodically for specific activities that must be completed" [Consultant, M, 49]. 
"To cut down fixed costs, I work in a network. I still work alone, but in a network that means that if I have an important project and I need a collaborator I summon the person ad hoc. But I am not looking for a young professional, I look for a peer, who might be younger than me, but who I pay only when I get my revenue" [Consultant, M, 52].

The example that represents the clearest concretization of shamrock organization's ideal type is a partnership of three consultants, active in the area of Milano. The three business partners devote approximately $30-40 \%$ of their working time to commercial tasks and fund raising, with the aim of generating enough turn-over to sustain their organization. When a project is assigned to their partnership, they usually carry out an evaluation: if the tasks are simple enough, they outsource it to their network of collaborators. Core professionals work on operational activities only when they need interventions that go beyond routine professional practice, requiring the expertise of a senior consultant.

"That is to say, we only deal with projects that require intervention. Then, for other matters, we cannot execute these personally and so we do it based on what the level of difficulty is, or else we ask [for] the help of one of the consultants collaborating with us" [Consultant, M, 45].

As such, shamrock organizations act as a market signal, and core professionals are more inclined to invest efforts into the consolidation of their brand, due to the possibility of providing professional expertise directly. The shared organizational environment promotes the development of shared methodologies and approaches, which signals credibility and helps to maintain a positive reputation in the market. The organization acts as a guarantee for the consultant and partners when dealing with their clients, but it also allows collaborators to complete the work sourced by another person. However, these organizational forms are looser than partnerships, as they only give structured 
positions in the organization to core members. Core members in this case are not those who provide professional services, but those who are endowed with more managerial tasks - i.e. commercial activities, fundraising, and organization of human resources. Despite this, being a collaborator of a shamrock organization is also a good strategy for solo freelancers: it enables access to a network that can provide assignments that complement the professional activity raised by the professional directly from the market.

\author{
"I have always followed this strategy. I had one or two main clients from which I \\ earned my profit, and then three to four, even more buyers that supported me with \\ relations, communication and learning. These last projects are less remunerative, \\ but I usually learn more, while the more remunerative projects usually have a \\ lower rate of innovation. The risk that I might incur is clear: if I only pursue less \\ innovative projects when the assignment ends I might find myself out of the \\ market, while having relations with three to four larger consultancy firms avoids \\ this risk, as I do special activities for them" [Consultant, M, 61].
}

In conclusion, successful stories as those presented here offer some insights to understand the increased importance of personal and networked reputation (Gluckler and Armbruster 2003) that sustains the activity of self-employed professionals due to the increasing prevalence of small organizational forms. Organizations can act as forms of market signaling, but they are also instruments to provide a kind of 'life vest' in case of any personal problems on the part of the professionals. In this way, organizations are substitutes for social protections that allow practitioners to cope with market pressures in several ways: organizations can continue operating in the absence of practitioners (at least temporarily), representing an income source even if an individual is not able to work for a certain period. They are also structures that can be expanded and compressed in line with market fluctuations, protecting core members from the risks of unstable revenues, which are softened by networks. However, the type of organization that is pursued by 
self-employed professionals is far distant from the model of large bureaus: built on the basic division between commercial and operational tasks, it allows for the effective distribution of competencies amongst partners in order to create an economically sustainable environment, while respecting the natural inclinations of those who belong to the association. In the analysis, two emergent types of association were particularly interesting: in the example of architects, the interprofessional associations survive better in the market not only for a division of work, but also for completing the different skill sets of its members; in the example of consultants, in the shamrock organization the commercial activities are retained to be pursued by the core members, while the operational tasks are outsourced to a wider and more flexible network of collaborators.

These forms of organization sit at an intermediate level between the traditional archetype of professional partnership and the solo practitioners. In these organizations, contacts are more institutionalized compared to the ego-centred networks of solo practitioners, as they are based on an intense exchange of assignments that typically originate from the overspill of the personal networks of core professionals.

\section{Conclusion}

This paper has offered insights into the debate currently ongoing in sociology of professional groups, focusing on the reconcilability of professional and market logics. These empirical results, consistent with recent studies (Evetts 2011a; Muzio and Kirkpatrick 2011; Butler et al. 2012; Noordegraaf 2015), demonstrate that professional groups can actually work well inside organizations, and empirical data has shown that professionalism is more complex, multidimensional, and multi-layered compared to its classical theorization. In reality, as already argued by Cooper et al. (1996), ideas of professionalism and partnership have changed, due in part 
to shifts in discourses in the wider institutional context. These changes in discourse themselves have altered the interpretation of organizational structures and systems.

In the cases analyzed in this paper, the recourse to organization was an agency strategy used bottom-up by independently employed practitioners to cope with market pressures. In this strategy, self-employed professionals associate themselves in order to overcome the most negative consequences of being alone in the market. These strategies evolve from the personal contacts that the individual has in the network in which they have always performed. In the past, self-employed professionals in Italy established professional partnerships between colleagues (in the form of associated firms) primarily to share fixed costs (rent, administrative staff, and so on). This article has argued that today new organizational trends are emerging, often based on inter-professional networking and solidarity mechanisms, in order to survive the challenges emerging in times of market crisis and welfare austerity. In the current situation, public regulation has been unable to evolve according to changing contextual elements. In particular, no effective social protection tools have been introduced to respond to the social needs of the growing number of female professionals in the market, nor to sustain young workers in their early practice, exposing them to mechanisms of exploitation and processes of marginalization (Saks 2014).

Presently, for a freelance architect or consultant, the network of contacts for which he or she provides services plays three basic roles:

i. It helps professionals find new business opportunities, without being dependent on larger firms, opportunities that are very often developed based on the suggestion of a different professional (i.e. an architect who needs a lawyer);

ii. It helps prevent loneliness in one's professional life, enabling individuals not only to exchange opinions and suggestions on specific problems in the field, but also providing 
a form of "mutual aid" and a space for reciprocity (especially for women, in the form of protection in case of maternity leave or other care-related duties);

iii. It helps professionals in their business from an entrepreneurial point of view; if they get a job that they are unable to work on due to the growing complexity of the market-request and/or bureaucracy, they can turn to their inter-professional network to find the right professional, without losing the client.

Institutionalizing a network of contacts into organization, even in a loose and liquid form as proposed by the interviewees, specifically responds to calls for protection from the market, in different ways, not only by enabling peer help in the most vulnerable moments of a person's life (e.g. leave, illness, accident), but also by compensating for fluctuations of the market. To achieve this result, those who promote these organizational forms are willing to concentrate more on managerial tasks, leaving the routine professional activities to marginal members of their organizational networks, without perceiving this mechanism as a potential threat to their professional autonomy. In our investigation, organization and professionalism progressive interplay representing an opportunity to prevent the descent into a condition of vulnerability that is increasingly characterizing self-employed individuals (Hipp et al. 2015). Stated briefly, in view of the absence of public regulation protecting them from the risks of an increasingly difficult market, the search for an organizational structure constitutes a new form of professionalism that acts as a self-made system of preservation and defense against the unpredictability of the market. Indeed, the bottom-up solution identified by a growing number of professionals in Italy lies in between the frustration of de-professionalization dynamics and loss of autonomy in large organizations, and exposure to the high risks of being a solo-professional in the changing market. 


\section{References}

Abbott, A. 1988. The System of professions. An essay on the division of expert labor. Chicago: University of Chicago Press.

Alvesson, M. 2001. “Knowledge Work: Ambiguity, Image and Identity”. Human Relations 54(7): $863-886$.

Architect Council of Europe (ACE). 2014. The Architectural Profession in Europe 2014. A sector study. Retrieved July 13, 2015 (www.ace-cae.eu/fileadmin/New_Upload/7.

Publications/Sector_Study/2014/EN/2014_EN_FULL.pdf).

ASSOCONSULT. 2011. Osservatorio del management consulting in Italia. Rapporto 2010/2011.

Retrieved June 6, 2017

(www.assoconsult.org/default.aspx?file=/file/osservatorio/4_Osservatorio_2011_finale.pdf).

ASSOCONSULT. 2015. Osservatorio del management consulting in Italia. 6 Rapporto 2014/2015. Retrieved June 27, 2017 (http://www.assoconsult.org/uploads/pages/attachments/17_rapportoosservatorio-2015.pdf).

Bagnasco, A. 1977. Tre Italie. La problematica territoriale dello sviluppo italiano. Bologna: Il Mulino Editore.

Boltanski, L. and E. Chiapello. 1999. Le Nouvelle Esprit du Capitalisme. Paris: Gallimard.

Brint, S. 2001. 'Professionals and the 'Knowledge Economy:' Rethinking the Theory of Postindustrial Society.” Current Sociology 49(4): 101-132.

Brock, D. M. 2006. "The changing professional organization: A review of competing archetypes”. International Journal of Management Reviews 8(3): 157-174. 
Bucher, R. and J. Stelling. 1969. "Characteristics of professional organizations" Journal of Health and Sociological Behavior 10 (1): 3-15.

Butler, N., S. Chillas, and S. Muhr. 2012. "Professions at the Margins." Ephemera 12(3): 259-272.

Cassese, S. 1999. Professioni e ordini professionali in Europa. Confronto fra Italia, Francia e Inghilterra. Milano: Il Sole 24ore Edizioni.

Castells, M. 1996. The Rise of the Network Society, The Information Age: Economy, Society and Culture, Vol. I. Oxford: Blackwell.

Cohen, L., A. Wilkinson, J. Arnold and R. Finn. 2005. 'Remember I'm the bloody architect!': Architects, organizations and discourses of profession". Work, Employment \& Society 19(4): 775796.

Colli, A. 2010. "Dwarf giants, giant dwarfs. Reflections about the Italian "industrial demography" at the beginning of the new millennium". Journal of Modern Italian Studies 15(1): 43-60.

Cooper, D.J., C.R. Hinings, R. Greenwood, and J.L. Brown. 1996. "Sedimentation and transformation in organizational change: the case of Canadian law firms." Organization Studies 17 (4): $623-647$

Cucca, R. and L. Maestripieri. 2014. "Architects and Consultants between Formal Regulation and Organised Professionalism.” CAMBIO 7: 25-40.

Currie, G., N. Burgess and P. Tuck. 2016. "The (un)desirability of hybrid managers as "controlled" professionals: comparative cases of tax and healthcare professionals." Journal of Professions and Organization 3: 142-153.

Devine, F., J. Britton, R. Mellor and P. Halfpenny. 2000. "Professional work and professional careers in Manchester's business and financial sector.” Work, Employment \& Society 14(3): 521540. 
Evetts, J. 2003. "Reinterpreting professionalism: as discourse of social control and occupational change'. In Conceptual and Comparative Studies of Continental and Anglo-American Professions, edited by J. Evetts and L. Svensson. Göteborg: Department of Sociology, Göteborg University. Evetts, J. 2009. "New Professionalism and New Public Management: Changes, Continuities and Consequences." Comparative Sociology 8(2): 247-266.

Evetts, J. 2011a. “A new professionalism? Challenges and opportunities.” Current Sociology 59(4): $406-422$.

Evetts, J. 2011b. "Sociological Analysis of Professionalism: Past, Present and Future." Comparative Sociology 10(1): 1-37.

Evetts, J. 2013. "Professionalism: Value and ideology." Current Sociology 61(5-6): 778-796.

Faulconbridge, J. R. and D. Muzio. 2007. "Reinserting the professional into the study of globalizing professional service firms: the case of law." Global Networks 7(3): 249-270.

Fincham, R. 2006. "Knowledge work as occupational strategy: comparing IT and management consulting." New Technology, Work and Employment 21(1): 16-28.

Fincham, R. 2012. "Expert labour as a differentiated category: Power, knowledge and organisation. New Technology." Work and Employment 27(3): 208-223.

Freidson, E. 2001. Professionalism. The Third Logic. New York: Polity Press \& Blackwell Publishers.

Gluckler, J. and Armbrüster, T. 2003. "Bridging Uncertainty in Management Consulting: The Mechanisms of Trust and Networked Reputation." Organization Studies 24 (2): 269-297. 
Greenwood, R. and Empson, L. 2003. “The Professional Partnership: Relic or Exemplary Form of Governance?" Organization Studies 24 (6): 909-933.

Hanlon, G. 1996. "Casino Capitalism" and the Rise of the Commercialised" Service Class—an Examination of the Accountant." Critical Perspectives on Accounting 7: 339-363.

Hanlon, G. 1998. "Professionalism as Enterprise: Service Class Politics and the Redefinition of Professionalism." Sociology 32(1): 43-63.

Haug, M. 1973. "Deprofessionalization: An Alternative Hypothesis for the Future.” Sociological Review Monograph 20: 195-211.

Haug, M. 1975. “The Deprofessionalization of Everyone.” Sociological Focus 8: 197-214.

Hipp, L., J. Bernhardt and J. Allmendinger. 2015. "Institutions and the Prevalence of Nonstandard Employment." Socio-Economic Review 13(2): 351-377.

Hodgson, D., S. Paton and D. Muzio. 2015. "Something Old, Something New?: Competing Logics and the Hybrid Nature of New Corporate Professions." British Journal of Management 26(4): 745759.

Kipping M. , Kirkpatrick, M., Muzio D., K.I. 2006. “Overly controlled or out of control? Management consultants and the new corporate professionalism." Pp. 153-165 in Production Values: Futures for professionalism, edited by J. Craigh. London, DEMOS.

Leicht, K. T. and M. L. Fennell. 1997. "The Changing Organizational Context of Professional Work.” Annual Review of Sociology 23: 215-231.

Leicht, K. 2017 "The future of professional work: It's not what you think", Keynote plenary session - ISA RC52 "Sociology of Professional Groups” Interim Meeting "Change in Professions and 
Professionalism - Signs and Directions", Oslo and Akershus University College of Applied Sciences, Oslo, 8-10 June 2017. Unpublished paper.

Maestripieri, L. 2013 Consulenti di Management. Il professionalismo organizzativo nel lavoro di conoscenza. Torino: L’Harmattan Italia.

Maestripieri, L. 2016. "Professionalization at work: The case of Italian management consultants." Ephemera: Theory and Politics in Organization 16(2): 31-52.

Malatesta, M. 2006. Professionisti e gentiluomini. Storia degli ordini professionali nell'Europa moderna. Torino: Giulio Einaudi Editore.

Malhotra, N. and T. Morris. 2009. "Heterogeneity in professional service firms". Journal of Management Studies 46(6): 895-922.

McKinlay, J. and J. Stoeckle. 1988. "Corporatization and the Social Transformation of Doctoring." International Journal of Health Services 18(2): 191-205.

Micelotta, E. R. and M. Washington. 2013. "Institutions and Maintenance: The Repair Work of Italian Professions”. Organization Studies 34(8): 1137-1170.

Mintzberg H. 1979 The Structuring of Organization. New York: Prentice Hall.

Mintzberg H. 1983 Power In and Around Organisations. New York: Prentice Hall.

Morris, T. 2009. "What do we mean by professional?" In Organizing Words: A Critical Thesaurus for Social and Organization Studies, edited by Y. Gabriel. Oxford: Oxford University Press: 234235 
Muzio, D., Ackroyd S. and J. F. Chanlat. 2008. "Introduction: Lawyers, Doctors and Business Consultants." Pp. 1-28 in Redirections in the Study of Expert Labour, edited by S. Ackroyd, D. Muzio and J. F. Chanlat. Berlin: Springer.

Muzio, D., D. Hodgson, J. R. Faulconbridge, J. Beaverstock and S. Hall. 2011. "Towards corporate professionalization: The case of project management, management consultancy and executive search." Current Sociology 59(4): 443-464.

Muzio, D. and I. Kirkpatrick. 2011. "Introduction: Professions and Organizations - a Conceptual Framework." Current Sociology 59(4): 389-405.

Muzio, D., D. M. Brock and R. Suddaby. 2013. "Professions and institutional change: Towards an institutionalist sociology of the professions." Journal of Management Studies 50(5): 699-721.

Neal, M. and J. Morgan. 2000. "The Professionalization of Everyone? A Comparative Study of the Development of the Professions in the United Kingdom and Germany.” European Sociological Review 16(1): 9-26.

Noordegraaf, M. 2007. "From "Pure” to "Hybrid” Professionalism: Present-Day Professionalism in Ambiguous Public Domains.” Administration \& Society 39(6): 761-785.

Noordegraaf, M. 2011. "Risky Business: How Professionals and Professional Fields (Must) Deal with Organizational Issues.” Organization Studies 32(10): 1349-1371.

Noordegraaf, M. and W. Schinkel. 2011. "Professional Capital Contested: A Bourdieusian Analysis of Conflicts between Professionals and Managers." Comparative Sociology 10: 97-125.

Noordegraaf, M. 2016. "Reconfiguring Professional Work: Changing Forms of Professionalism in Public Services.” Administration \& Society 48(7): 783 - 810 
Noordegraaf, M., M. van der Steen and M. van Twist. 2014. "Fragmented or connective professionalism? Strategies for professionalizing the work of strategists and other (organizational) professionals.” Public Administration 92(1): 21-38.

Noordegraaf, M. 2015. "Hybrid Professionalism and Beyond: (New) Forms of Public Professionalism in Changing Organizational and Societal Contexts." Journal of Professions and Organization 2(2): 1-20.

Ranci, C. 2012. Partite Iva. Il lavoro autonomo nella crisi italiana. Bologna: Il Mulino Editore.

Reyneri E. (2017) “Lavoro indipendente sul viale del tramonto.” LaVoce. Retrieved October 31, 2017 (http://www.lavoce.info/archives/49280/lavoro-sempre-meno-indipendente/).

Saks, M., 2014. "Professions, marginality and inequalities." Sociopedia.isa. Retrieved June 26, 2017 (http://www.sagepub.net/isa/admin/viewPDF.aspx?\&art=ProfessionsMarginality.pdf).

Schott, C., D. van Kleef and M. Noordegraaf. 2016. "Confused professionals? Capacities to cope with pressures on professional work.” Public Management Review 18(4): 583-610.

Suddaby, R., Y. Gendron and H. Lam. 2009. "The organizational context of professionalism in accounting." Accounting, Organizations and Society 34(3-4): 409-427.

van den Born, A. and A. van Witteloostuijn. 2013. "Drivers of freelance career success." Journal of Organizational Behaviour 34(1): 24-46.

Waring, J. 2014. "Restratification, Hybridity and Professional Elites: Questions of Power, Identity and Relational Contingency at the Points of 'Professional-Organisational Intersection'.” Sociology Compass 8(6): 688-704.

Wilensky, H. 1964. “The Professionalization of Everyone?” The American Journal of Sociology 70(2): $137-158$. 